\title{
The Relationship of Marital Satisfaction and Life Satisfaction with Spiritual Orientation: The Mediating Role of Sacrifice and Sensitivity
}

\author{
Mine SAYIN2® \\ Bartın University
}

\author{
İbrahim Halil DEMİR ${ }^{3}$ \\ Yüzüncü Yıl University
}

\author{
Füsun Ekşi ${ }^{3}$ [1] \\ Istanbul Medeniyet University
}

\begin{abstract}
The purpose of this research is to test the proposed structural model related to the mediating role of sensitivity and sacrifice on the relationship of marital satisfaction and life satisfaction with married individuals' spiritual orientations. The research has been performed with a total of 454 married individuals living in Turkey, of which $280(61.7 \%)$ are females and 174 (38.3\%) are males. The Relationship Happiness Questionnaire, Satisfaction with Life Scale, Spiritual Orientation Scale, Sensitivity Scale, and Satisfaction with Sacrifice Scale have been used as the data collection tools. The programs SPSS 21.0 and AMOS 20.0 have been used in the data analyses. The structural model proposed in the research has been tested using the structural equation model. The fit-index values from the tested model have been determined to show good fit and the values to be statistically significant. As a result, the structural model established for testing the mediating roles of sensitivity and sacrifice on the relationship of marital satisfaction and life satisfaction with spiritual orientation has been verified; and sacrifice and sensitivity are seen to have a partial mediating role in the model.
\end{abstract}

\section{Keywords}

Marital satisfaction $\bullet$ life satisfaction $\bullet$ spiritual orientation $\bullet$ sacrifice $\bullet$ sensitivity

\section{Manevi Yönelim ile Evlilik Doyumu ve Yaşam Doyumu Arasındaki İlişki: Fedakarlık ve Duyarlığın Aracı Rolü}

Öz

Bu araştırmanın amacı, evli bireylerin manevi yönelimleri ile evlilik doyumları ve yaşam doyumları arasındaki ilişkide duyarlılık ve fedakarlıklarının aracılık rolüne ilişkin önerilen yapısal modelin test edilmesidir. Araştırma, Türkiye'de yaşayan 280'i kadın (\%61.7) ve 174'ü erkek (\%38.3) olmak üzere toplam 454 evli birey ile gerçekleştirilmiştir. Veri toplama aracı olarak İlişkilerde Mutluluk Ölçeği, Yaşam Doyumu Ölçeği, Manevi Yönelim Ölç̧eği, Duyarlık Ölçeği ve Fedakarlık Doyum Ölçeği kullanılmıştır. Verilerin analizinde SPSS 21.0 ve AMOS 20.0 programları kullanılmıştır. Araştırmada önerilen yapısal model Yapısal Eşitlik Modeli ile test edilmiştir. Test edilen modelin uyum indeksi değerlerinin iyi uyum gösterdiği ve elde edilen değerlerin istatistiksel olarak anlamlı olduğu tespit edilmiştir. Sonuç olarak, manevi yönelim ile evlilik doyumu ve yaşam doyumu arasındaki ilişkide duyarlılık ve fedakarlığın aracı rolünü test etmek için kurulan yapısal model doğrulanmış ve duyarlılık ile fedakarlığın modelde kısmi aracılık rolü olduğu görülmüştür.

\section{Anahtar Kelimeler}

Evlilik doyumu $\bullet$ yaşam doyumu $\bullet$ manevi yönelim $\bullet$ fedakarlık $•$ duyarlılık

\footnotetext{
1 Correspondence to: Bartın University, Faculty of Education, Department of the Psychological Counseling and Guidance Email: minesayin0332@gmail.com

2 Yüzüncü Yıl University, Faculty of Education, Department of the Psychological Counseling and Guidance ihalil_demir@ hotmail.com

3 Faculty of Education, Department of Psychological Counseling and Guidance, İstanbul Medeniyet University, 34722 İstanbul, Turkey. E-mail: fusun.eksi@medeniyet.edu.tr
}

Citation: Sayın, M, Demir, I.H. \& Eksi, F. (2019). The relationship of marital satisfaction and life satisfaction with spiritual orientation: the mediating role of sacrifice and sensitivity. Spiritual Psychology and Counseling, 4, $237-256$. http://dx.doi.org/10.37898/spc.2019.4.3.083 
Life satisfaction is a concept that has been examined throughout human history, and its source still elicits curiosity. Life satisfaction, also known as happiness, has been addressed by philosophers as well and is seen as one of the major sources of motivation in human behavior (Özer \& Karabulut, 2003). Many definitions regarding life satisfaction may be encountered when looking at the performed studies. Neugarten, Havighurst, and Tobin (1961), who first used life satisfaction, expressed it as the state obtained by the comparison that is done between expectations and actual circumstances. Namely, life satisfaction is the evaluation individuals do between what they want to have and what they do have (Dilmaç \& Ekşi, 2008). According to Arasan (2010), life satisfaction is the conclusion individuals reach as a result of comparing what they have obtained with what they want to obtain. Life satisfaction can be defined as: the satisfaction individuals obtain as a result of evaluations made toward the past, present, and future (Diener \& Lucas, 1999); the levels of happiness one presents in marriage, work, and different areas (Myers \& Diener, 1995); the attitude one shows toward one's life apart from work life (Pavot \& Diener, 1993); and the positive evaluation of one's life according to self-determined criteria (Diener, Emmons, Larsen, \& Griffin, 1985).

Many factors are found to positively and negatively impact individuals' life satisfaction. Keser (2005) listed the factors affecting life satisfaction as: feeling happy in daily life, being able to make sense of life, having positive identity development, being in good physical health, and having sufficient levels of economic income and social relations. Flanagan (1978) expressed elements such as selfconfidence, establishing positive relations with the social environment, helping others, being able to participate in local endeavors, being sociable, and being able to develop enjoyable activities as the factors affecting life satisfaction. Social and romantic relations represent a significant place for life satisfaction because having people such as friends, spouses, and children provides social support, shares free time, and helps financially foster life satisfaction (Adams, 1971). Being married or sharing a romantic relationship and having a social environment positively affect life satisfaction (Diener, Gohm, Suh, \& Oishi, 2000; Diener \& Diener McGavran, 2008). In addition, when looking at the literature, marital satisfaction's significant and positive relationship with life satisfaction has been revealed through the performed studies (Ng, Loy, Gudmunson, \& Cheong, 2009; Perrone, Webb, \& Blalock, 2005)

Marriage, which is seen as a form of romantic and institutional relationship between a man and woman, is able to be accepted as a turning point in individuals' social lives. While marriage is accepted as one of the most special forms of romantic relations, it is also an institution that is one of the fundamental conditions for establishing a family (Erdoğan \& Uslu, 2018). Marriage is considered to be an institution that sustains societies, and the institution of marriage needs to be healthy for a strong and happy 
society (Özmen-Süataç, 2010). A healthy marriage is possible by spouses' meeting each other's needs and expectations and sustaining their marriage in harmony. In this context, studies performed on marriage have researched concepts such as marital harmony, marital satisfaction, and sustaining marriage (Tutarel-Kışlak \& Göztepe, 2012). Concepts such as marital quality, marital harmony, and marital happiness are also seen to have been used in place of marital satisfaction (Y1lmaz-Güre, 2001; Fincham \& Bradbury, 1987). This study has chosen the frequently used concept of marital satisfaction.

Marital satisfaction is the perceptions related to how and the degree to which spouses meet their needs in the marital relationship (Spainer \& Lewis, 1980). According to Ahmadi \& Hossein-Abadi (2009) and Bradbury, Fincham \& Beach (2000) marital satisfaction is the state of restoring balance as a result of couples' meeting psychological needs such as love, comfort, and closeness and physiological needs such as sexuality and attention. Marital satisfaction is the psychological satisfaction that couples feel from the individual and environmental dimensions that exist for the institution of marriage. The individual factors are the spouses' attitudes, styles of self-expression, sexual satisfaction, affection styles, and forms of communication. Environmental factors are the spouses' dominance, the conditions for sharing problems, work and income status, and status of equality when deciding on any issues (Çelik, 2015; Call \& Heaton, 1997).

According to the performed research and their results, many factors are found to affect marital satisfaction. Some of these are individual, some are biological, some are socioeconomic, and some are relational/familial factors. Conditions and experiences such as empathetic and healthy communication, the level of happiness in the parents' marriage, a high level of the marriage's approval from family and friends, making material and spiritual investments in the marital relationship, a common history of religion and ethnic identity, and having formed good relations with parents during childhood have been identified as important factors for marital satisfaction (Ersanlı \& Kalkan, 2008; Kasapoğlu, 2007; Dowlatabadi, Saadat, \& Jahangiri, 2013). Spiritual factors such as strong spiritual values between spouses, spouses' respect for one another, fidelity in sex life, coming forward to forgive and be forgiven, and being compassionate and understanding also affect marital satisfaction (Çă̆ \& Yıldırım, 2013).

One of the relationships also investigated in this study is the relationship of life satisfaction and marital satisfaction with spiritual orientation. Spirituality is expressed as one's interconnection with love, the self, and nature/others. One's connection with love refers to being interconnected to a higher power, God, or an entity beyond humans. Connection to the self contains features such as being at peace with one's self, searching and finding the meaning of one's life, being aware of self-consciousness, and being 
genuine. Lastly, being interconnected with nature and others refers to having feelings of tenderness, compassion, admiration, and gratitude (Sweney \& Witmer, 1991). According to Hills et al. (2000), three different orientations are emphasized while defining spirituality: 1) theologically oriented spirituality that is narrow, broad, or comprehensive in thought and practice, 2) world-oriented spirituality based on ecology and nature, and 3) humanist-oriented spirituality that emphasizes human success and potential. This research examines humanist-oriented spirituality. According to Elkins, Hedstrom, Hughes, Leaf and Saunders (1988), who took a humanistic understanding of spirituality as their basis, spirituality consists of nine themes. These themes are listed as: belief that life has meaning, objective mission, believing in a transcendental dimension, paying attention to material values as much as necessary, altruism, possessing ideals, accepting pain and suffering in life, and lastly spiritual gains.

The behavior of sacrifice, which is one of the mediating variables examined in this study, is defined as an individual in a marriage relationship abandoning their self-interests for the wellbeing of one's relationship or partner (Van Lange et al., 1997). In studies that have been done on sacrifice as well as the limited number of studies done on sacrifice and marital relations, partners who show sacrifice in relationships are found to get more satisfaction and have more interconnectedness in their relationships (Van Lange et al., 1997); individuals, even if their marriage provides low levels of satisfaction, continue their marriage because of the sacrifices they have made (Rusbult, Bissonette, Arriaga, \& Cox, 1998). Individuals who think the sacrifices done in relationships are both compatible with their personal interests and beneficial for the relationship are stated as having high levels of commitment and marital satisfaction; however, people who think sacrificing harms their interests because of the sacrifices they have done in the past in relationships are said to have low levels of commitment and marital satisfaction in the relationship (Whitton, Stanley, \& Markman, 2007). According to some of the performed studies, religion and spirituality are revealed to positively impact people's self-sacrificing behaviors, their empathetic and altruistic tendencies, and sensitivities toward helping others (Bennett \& Einolf, 2017; Huber \& MacDonald, 2012). McDonald, Olson, Lanning, Goddard, and Marshall (2018), in their study researching the effect of religiousness, forgiveness, and empathy between spouses on marital harmony, determined participation in religious services and empathy between spouses to have a positive impact on married individuals' marital harmony.

Sensitivity, which is another mediating variable examined in this study, is expressed as the state of thought, feeling, and behavior contained in conscious sharing and kindness where the individual: identifies with the person they live with without judging their troubles, pains, or problems; does not refrain from addressing or sharing these problems; and helps the other person overcome these difficult situations (Neff, 
2003). According to Gilbert and Irons (2005), sensitivity is defined in the forms of empathy, sympathy, paying attention to one's own and other's wellbeing, having a non-judgmental attitude, being sensitive towards one's own and other's situations, and being tolerant toward stress. Sensitivity includes being aware of the suffering due to a person's problems and feeling the desire to facilitate the person overcoming these troubles and problems. In addition, sensitivity allows one to accept that everyone can make mistakes and no one is perfect and to approach others politely and patiently, without prejudice (Neff, Kirkpatrick, \& Rude, 2007). Studies that have been done on sensitivity have determined sensitivity to have a positive relationship with the factors that positively affect a person's wellbeing, such as helpfulness, empathy, social support, volunteerism (Sprecher \& Fehr, 2005), life satisfaction, emotional intelligence, and social support (Neff, 2003). According to Stonsy (2004), sensitivity among family members impacts the solving of many problems.

As a result, value is seen in investigating how sensitivity and sacrifices mediate the relationship between marital satisfaction and life satisfaction through married individuals' spiritual orientations, and the decision has been made for this to be done in the current study.

\section{Method}

\section{Research Model}

This study uses the predictive correlational design in the relational survey model for the purpose of revealing the direct and indirect relationships among spiritual orientation, sacrifice, and sensitivity with life satisfaction and marital satisfaction; the study tests the established model using the structural equation model in order to examine the mediating role of sacrifice and sensitivity on the relationship of life satisfaction and marital satisfaction with spiritual orientation.

\section{The Study Group}

The study group of the research is formed of 454 married individuals, of whom $280(61.7 \%)$ are female and $174(38.3 \%)$ are male and who have been identified using the maximum diversity sampling method, a purposeful sampling method. Of the individuals who form the sample group, 144 are between 17-30 years old, 201 are between 31-40 years old, and 109 are between 41-60 years old. When examining how long the participants have been married, 190 are seen to have been married for 1-5 years, 93 for 6-10 years, 109 for 11-20 years, and 62 for over 20 years. With respect to educational level, 36 of the participants have a primary-school, 86 a high-school, 242 an undergraduate, and 90 a post-graduate level of education. Lastly, 439 of the participants stated having religious beliefs, and 15 stated not having religious beliefs. 


\section{Data Collection Tools}

The Relationship Happiness Questionnaire. The research uses the Relationship Happiness Questionnaire developed by Fletcher, Fitness, and Blampied (1990) for the purpose of measuring marital satisfaction. The Turkish validity and reliability study of the scale for married individuals was conducted by Tuterel-Kışlak (2002). The scale is a 7-point Likert-type scale consisting of six items. The scale items measure perceptions related to love, happiness, general satisfaction, relationship stability, severity of problems, and level of commitment/obligation in the relationship. The lowest obtainable score on the scale is 6 and the highest is 42 . The original coefficient of internal consistency for the scale was .87 . The test-retest reliability coefficient obtained after two applications varying between two and seven weeks is .90 . In the criterion validity study, which used the Triangular Love Scale (Sternberg, 1997), the validity coefficient has been found as .82 .

Satisfaction with Life Scale. This study uses the Satisfaction with Life Scale (SWL), developed by Diener, Emmans, Lorsen, and Giffin (1985), for the purpose of identifying married individuals' life satisfaction. The scale has one dimension and consists of five items. The scale has a Likert-type ranking with options from 1 to 5 ranging from "I completely disagree" to "I fully agree." The scale's translation and adaptation to Turkish was conducted by Dağlı and Baysal (2016). The scale's Cronbach alpha of internal consistency has been determined as .88 and its testretest reliability as .97 . The results from the performed factor analysis reveal the Satisfaction with Life Scale to show a single-factor structure, just like the original scale, and to again consist of five items like the original scale.

Spiritual Orientation Scale. This scale was developed by Kasapoğlu (2015) for the purpose of evaluating individuals' spiritual orientations. Exploratory and confirmatory factor analyses have been performed in order to test the structural validity of the Spiritual Orientation Scale. The scale has been determined to be formed from one factor that explains $47.5 \%$ of the total variance, and the fit indexes of the model, which is represented by one dimension, has been determined to be appropriate $\left(\chi^{2}=239.718, s d=100, p=.000\right), \chi^{2} \mathrm{sd}=2.39, R M S E A=0.06, R M R=$ $0.05, G F I=0.93, A G F I=0.90, C F I=0.95, I F I=0.95, N F I=0.92)$. Thus a 7-point Likert-type scale consisting of 16 items has emerged; 277 university students (172 females, 105 males) participated in the scale's criterion-based validity and reliability studies. The validity of similar scales have been found with a correlation of $r=.57$ and $p<.01$. When examining the scale's reliability, Cronbach's alpha has been found as $\alpha=.87$ and the test-retest reliability as $r=.84$. These results show the scale to be a valid and reliable measuring tool.

Sensitivity Scale. The Sensitivity Scale, developed by Demirci-Seyrek, Ersanl1, and Tunç (2016) for the purpose of determining adults' sensitivity levels, consists 
of 15 items and four sub-dimensions (compassion, sympathy, understanding, and humanistic). The scale's item-total score correlations have been found to range from .34 to $.62(p<.01)$. The goodness-of-fit indexes for the one-factor model are at very good levels $\left(\chi^{2}=160.87, s d=84, \chi^{2} \mathrm{sd}=2.24, A G F I=.96, G F I=.98, R M R=.022\right.$, $S R M R=.05, N N F I=.97, C F I=.98, R M S E A=.039)$. Results from the reliability analysis for the factors of compassion, sympathy, understanding, and humanistic are $.70, .65, .62$, and .55 , respectively. Cronbach's alpha for the overall scale has been found as $\boldsymbol{\alpha}=.81$.

Satisfaction with Sacrifice Scale. The Satisfaction with Sacrifice Scale (Whitton et al., 2007), which aims to measure the satisfaction provided by the sacrifices one makes, is a 7-point Likert-type ( 1 = I strongly disagree, $7=\mathrm{I}$ strongly agree $)$ measurement tool composed of six items (e.g., "Giving up things for my wife provides personal satisfaction"). Three items from the scale are reverse scored. The scores obtainable from the scale range from 6 to 42, with higher scores showing higher satisfaction being provided from the sacrifice made. The Turkish adaptation study of the scale was conducted by Topcu and Tezer (2013). The results of exploratory and confirmatory factor analyses yielded a one-factor structure for the scale. According to the results from the factor analysis performed for the purpose of examining the scale's construct validity, the factor loadings of the scale items are seen to vary between .72 and .31. The goodness-of-fit indexes for the one-factor model are at very good levels $\left(\chi^{2}=8.25, s d=6, \chi^{2} \mathrm{sd}=1.37, G F I=.98, C F I=.98, R M S E A=.06\right)$. Cronbach's alpha of internal consistency for the scale has been found as $\alpha=.74$.

\section{Data Analysis}

The data obtained from the data collection tools in the research have been analyzed using the programs SPSS 21.0 and AMOS 20.0. Whether or not the data show normal distribution has been examined first; after sorting out the extreme values, the data are seen to show normal distribution. Next, the variables' descriptive statistics and reliability coefficients have been examined. Afterward, analysis using the Pearson product-moment correlation technique has been performed to examine the relationships among the variables. The theoretical model directed at explaining the mediating role of sensitivity and sacrifice on the relationship of marriage satisfaction and life satisfaction with married individuals' spiritual orientation was then tested. A significance level of $p<.05$ has been accepted in the research.

\section{Findings}

This section of the research reports the conclusions obtained as a result of the data analyses. Before proceeding to the analyses that form the main purpose of the research, prerequisite analyses have been performed for the purpose of determining 
the data's suitability; later, the relationships among the variables are examined and the model obtained as a result of the path analysis developed for the purpose of testing the theoretical model is given.

Table 1.

Mean, Standard Deviation and Cronbach's Alpha Values of the Study Variables

\begin{tabular}{lcccc}
\hline Variables & $\mathbf{N}$ & $\overline{\mathbf{x}}$ & $\mathbf{\text { ss }}$ & Cronbach's Alpha \\
\hline Spiritual orientation & 454 & 99,92 & 15,17 &, 957 \\
Sensitivity & 454 & 64,38 & 6,28 &, 742 \\
Sacrifice & 454 & 28,89 & 7,60 &, 763 \\
Marital satisfaction & 454 & 24,91 & 4,52 &, 865 \\
Life Satisfaction & 454 & 18,24 & 4,10 &, 864 \\
\hline
\end{tabular}

When examining Table 1, values for the averages, standard deviations, and Cronbach's alpha are seen that belong to the variables of spiritual orientation, sensitivity, sacrifice, marital satisfaction, and life satisfaction. The obtained Cronbach's alpha values have been found respectively as .96 for the spiritual orientation scale, .74 for the sensitivity scale, .76 for the sacrifice scale, .87 for the happiness in the relationship scale, and .86 for the life satisfaction scale. The obtained reliability coefficient is seen to have a value higher than at $r>.70$.

\section{The Relationship Among the Variables of Marital Satisfaction, Life Satisfaction, Spiritual Orientation, Sensitivity, and Sacrifice}

Before testing the mediating role of sensitivity and sacrifice on the relationship of marital satisfaction and life satisfaction with married individuals' spiritual orientation, which is the main topic of the research, the correlational values among the variables must be appropriate for analysis. Therefore, the relationships among the variables that will be included in the research have been examined first. According to the analysis results, all the variables are seen in Table 2 to have a significant relationship with one another.

Table 2 .

Correlation Values of the Study Variables $(N=454)$

\begin{tabular}{|c|c|c|c|c|c|}
\hline Variables & 1 & 2 & 3 & 4 & 5 \\
\hline 1. Spiritual orientation & 1,00 & & & & \\
\hline 2. Sensitivity &, $371^{* *}$ & 1,00 & & & \\
\hline 3. Sacrifice &, $280^{* *}$ &, $151^{*}$ & 1,00 & & \\
\hline 4. Marital satisfaction &, $230^{* *}$ &, $127^{*}$ &, $491^{* *}$ & 1,00 & \\
\hline 5. Life Satisfaction &, $356^{* *}$ & $190^{* * *}$ & ,290** &, $514^{* *}$ & 1,00 \\
\hline
\end{tabular}

As seen in Table 2, the relationship of the married people who participated in the research with the variables of marital satisfaction and life satisfaction in terms of the variables of spiritual orientation, sensitivity, and sacrifice have been investigated using Pearson product-moment correlational analysis. According to the results of the 
Pearson correlational analysis, the variable of marital satisfaction is found to have positive relationships with the variables of spiritual orientation $(r=.23, p<.001)$, sensitivity $(r=.13, p<.05)$, and sacrifice $(r=.49, p<.001)$; and the variable of life satisfaction has positive relationships with the variables of spiritual orientation $(r=.36, p<.001)$, sensitivity $(r=.19, p<.001)$, and sacrifice $(r=.29, p<.001)$. Meanwhile, the relationship between marital satisfaction and life satisfaction have been found to be significantly positive $(r=.51, p<.001)$, as well as the relationships between spiritual orientation and sensitivity $(r=.37, p<.001)$, spiritual orientation and sacrifice $(r=.28, p<.001)$, and sensitivity and sacrifice $(r=.15, p<.05)$. This result shows that happiness in the relationship and life satisfaction increase as the levels of spiritual orientation, sensitivity, and sacrifice increase.

\section{Examining the Structural Model Established Among the Variables of Marital Satisfaction, Life Satisfaction, Spiritual Orientation, Sensitivity, and Sacrifice}

The structural equation model has been formed among the variables included in the research for the purpose of testing the mediating role of sensitivity and sacrifice on the relationship of marital satisfaction and life satisfaction with spiritual orientation, which has been the main topic of the research.

The direct relationships of marital satisfaction and life satisfaction with spiritual orientation have first been tested, and the obtained structural model (Model 1) is presented in Figure 1.

Figure 1.

The relational structural model on the relationships of the variables of marital satisfaction and life satisfaction with spiritual orientation (Model 1)

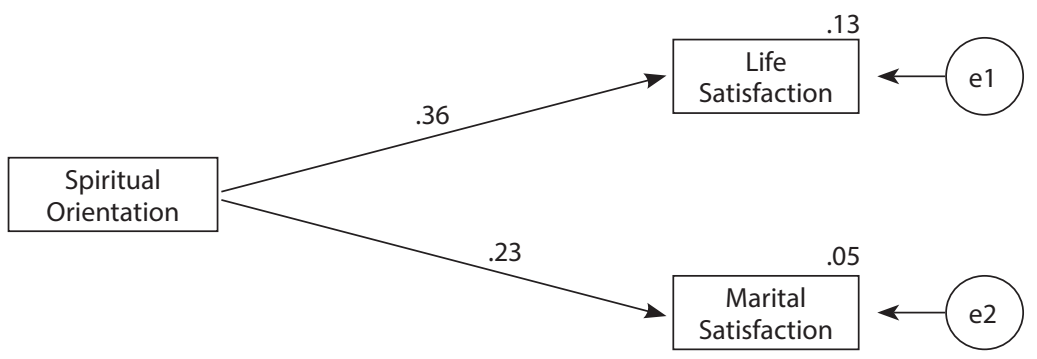

According to this model, the path coefficient showing the relationship between spiritual orientation and life satisfaction is seen as .36, and the path coefficient showing the relationship between spiritual orientation and marital satisfaction is seen as .23.

In the next step, sensitivity and sacrifice have been included as the mediating variables in the model on the relationship of marital satisfaction and life satisfaction 
with spiritual orientation, and the model has been tested. Model 2, which has been obtained as a result of the performed path analysis, is given in Figure 2.

Figure 2.

The relational structural model on the mediating role of sensitivity and sacrifice on the relationship of marital satisfaction and life satisfaction with spiritual orientation (Model 2)

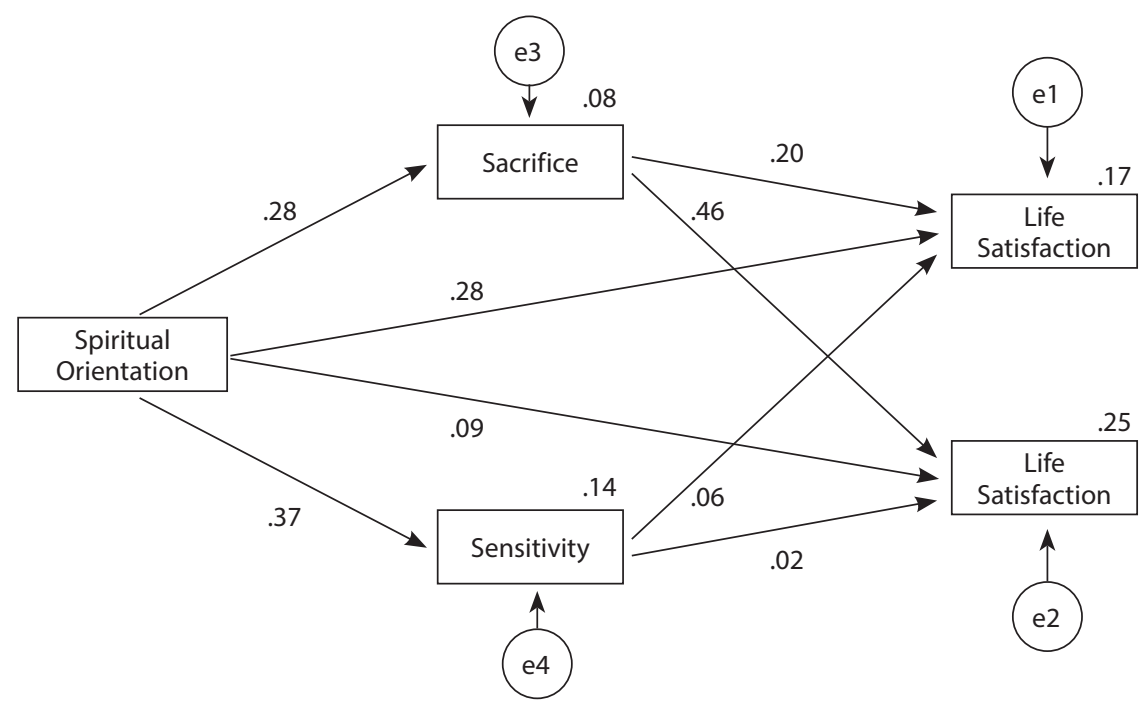

Analysis of the structural equation model has been performed for the purpose of investigating whether or not sacrifice and sensitivity mediate the relationship between spiritual orientation and marital satisfaction. In the structural model tested in this research, spiritual orientation is the external variable, marital satisfaction and life satisfaction are the internal variables, and sensitivity and sacrifice are the mediating variables.

As a result of the performed Pearson correlational analysis, the relationships among variables have been seen to be significant. However, when performing the structural model analysis, the relationship of sensitivity with life satisfaction and marital satisfaction is no longer seen to be significant. As is known, because of the large number of parameters in the structural model, the issue is that some variables take loadings from other variables (Hayes, 2018). A similar situation is also seen specific to our study. Accordingly, the variables of sensitivity and sacrifice are understood to have common loading values, and the common loading is understood to be received by the variable of sacrifice.

According to the obtained findings on the structural model, while spiritual orientation's direct influence on life satisfaction shows a path coefficient of $r=$ 0.36 in the first model, the path coefficient is seen to drop to $r=0.28$ in the second model by including the variables of sacrifice and sensitivity as mediating variables 
in the model. Meanwhile, while the direct impact of spiritual orientation on marital satisfaction in the first model shows a path coefficient of $r=0.23$, the path coefficient is seen to drop to $r=0.09$ in the second model by including the variables of sacrifice and sensitivity as mediating variables in the model. This decrease in the value of the path coefficient through the mediation of the variables of sensitivity and sacrifice shows the relationship that spiritual orientation has with marital satisfaction and life satisfaction to be partially explained by sacrifice and sensitivity. The obtained model shows a total of $17 \%$ of the variable of life satisfaction to be explained by sensitivity and sacrifice and a total of $25 \%$ of the variable of marital satisfaction to be explained by sensitivity and sacrifice.

The relational model on the mediating role of sensitivity and sacrifice on the relationship of marital satisfaction and life satisfaction with spiritual orientation is seen to be statistically significant. When examining the model-data fit values belonging to the structural model, the tested structural model is seen to show good fit and the obtained goodness-of-fit indexes are all seen to have good fit ranges $\left(\chi^{2} d f=\right.$ $1.26 ; R M S E A=.024 ; G F I=.999 ; S R M R=.00 ; N F I=.997 ; N N F I=.999 ; C F I=.999$; $R F I=.970)$. While examining the adequacy of the fit indexes of the model tested in the path analysis, Tabachnick and Fidell's (2001) values for acceptable and good fit have been taken into account.

Table 3.

Bootstrapping of Model

\begin{tabular}{|c|c|c|c|c|}
\hline \multirow{2}{*}{\multicolumn{2}{|c|}{$\begin{array}{l}\text { Model Paths } \\
\text { Model } 2\end{array}$}} & \multicolumn{3}{|c|}{ \%95 BCa Confidence Interval } \\
\hline & & Coefficient & Low & High \\
\hline \multicolumn{5}{|l|}{ Direct } \\
\hline SO & LS & 279 &, 163 & ,377 \\
\hline SENS. & LS &, 056 &,- 035 & ,155 \\
\hline SACR. & LS & ,203 &, 111 & ,287 \\
\hline SO & MS & ,091 &,- 015 &, 195 \\
\hline SENS. & MS &, 023 &,- 068 & , 109 \\
\hline SACR. & MS & ,462 & ,380 & ,548 \\
\hline SO & SENS. & ,371 & ,285 & ,456 \\
\hline $\mathrm{SO}$ & SACR. & ,280 &, 187 & ,365 \\
\hline \multicolumn{5}{|l|}{ Indirect } \\
\hline SO SE & SACR. LS & 078 & 035 &, 127 \\
\hline SO SE & SACR. MS & ,138 & ,084 & ,192 \\
\hline
\end{tabular}

Note: $L S=$ Life Satisfaction; $M S=$ Marital Satisfaction; $S O=$ Spiritual Orientation; SENS. = Sensitivity; $S A C R .=$ Sacrifice

When analyzing Table 3 where the results of the bootstrapping process are shown, the total values of the coefficients that were measured both directly and indirectly are seen to be significant. The mediating role of sensitivity and sacrifice on the relationship of spiritual orientation with life satisfaction has been identified 
as significant (bootstrap $=.078,95 \%$ CI $[.035, .127]$ ), and the mediating role of sensitivity and sacrifice on the relationship of spiritual orientation with marital satisfaction is also significant (bootstrap $=.138,95 \%$ CI $[.084, .192]$ ). In light of these obtained findings, spiritual orientation can be said to affect marital satisfaction and life satisfaction, and sensitivity and sacrifice can also be said to have a partially mediating role on this relationship.

\section{Discussion}

This research has examined the mediating role of sensitivity and sacrifice on the impact of married individuals' spiritual orientation over their happiness in marriage and life satisfaction. As a result of the research, spiritual orientation, sensitivity, and sacrifice are seen to significantly predict happiness in marriage and life satisfaction, with sensitivity and sacrifice having a mediating role on the relationship of happiness in marriage and life satisfaction with spiritual orientation. According to this result, the impact of married individuals' spiritual orientation on their marital satisfaction and life satisfaction shows variance depending on whether their sensitivity and sacrifice levels are high or low.

Marriage is a social institution that helps individuals to receive satisfaction from their lives (Hayward \& Zhang, 2006). Aside from having many factors that impact marital satisfaction (Tezer, 1997), which constitutes the essence of life satisfaction in terms of social and familial health, marital satisfaction also affects individuals psychologically. A healthy marriage directly impacts individuals' quality of life and allows for a healthier and better quality life by providing individuals with psychological, social, and economic benefits (Atta-Alla, 2009; Hünler \& Gençöz, 2003; Scheidler, 2008; Williams, 2003).

Marital harmony, which is seen as the success and functionality of married couples in the marriage and also contains the concepts of marital satisfaction, marital happiness, and pleasure (Ersanlı \& Kalkan, 2008), is an important underpinning of emotional wellbeing and happy living. Marital satisfaction, a variable that has been analyzed in this study, is an important element that impacts the satisfaction felt from life. Performed research shows marital satisfaction, which includes marital harmony and marriage happiness, to be significantly related to life satisfaction (Celenk \& van de Vijver, 2013a; Çelik \& Tümkaya, 2012; Heller, Watson, \& Ilies, 2006; PerroneMcGovern, Boo, \& Vannatter, 2012) and marital satisfaction to be a significant predictor of life satisfaction (Celenk \& van de Vijver, 2013b; Ng, Loy, Gudmunson, $\&$ Cheong, 2009). Studies have shown life satisfaction to increase as the duration of the marriage increases (Dikmen, 1995), and couples who experience problems in their marital relations and individuals who maintain an unhappy marriage have 
less life satisfaction (Hawkins \& Booth, 2005; Koydemir, Selış1k, \& Tezer, 2005; Yetim, 2001). Because individuals with higher marital satisfaction also have greater life satisfaction, these individuals also have lower susceptibility to depression and lower stress levels (Çelik, 2015).

When analyzing spiritual orientation, another variable of this research, spiritual orientation is seen to significantly and positively predict happiness in marriage and life satisfaction. This finding shows the results to be consistent with research that show a relationship to exist between life satisfaction and life pleasure with spiritual wellbeing (Alorani \& Alradaydeh, 2017; Sawatzky, Gadermann, \& Pesut, 2009) and that reveal individuals' belief systems, values, and spiritual wellbeing to impact marital satisfaction (Dowlatabadi et al., 2013; Kasapoğlu \& Yabanigül, 2018; Kublay \& Oktan, 2015; Zaheri et al., 2016). Factors such as strong spiritual values, belief in God, and commitment to religion are variables that predict marital satisfaction (Rosen-Grandon, Myers, \& Hattie, 2004). The values individuals adopt reflect onto their behaviors, attitudes, feelings, and thoughts. Therefore, individuals' values affect their approaches to marriage, their strategies for coping with problems encountered in the marriage process, their marital satisfaction, and the happiness they obtain (Kublay \& Oktan, 2015). Because ensuring happiness in marriage also contributes in great measure to the individual's general happiness and life satisfaction, spirituality can also be said to bring about life satisfaction by increasing marital satisfaction.

Research has revealed spirituality to positively impact the marital relationship and the parent-child relationship, and communication between spouses that contains spiritual and religious content has a positive effect on married individuals' marital satisfaction (David \& Stafford, 2015; Mahoney, 2010; Parker, Mandleco, OlsenRoper, Freeborn, \& Dyches, 2011; Carlson, Kirkpatrick, Hecker \& Killmer, 2002). In a study performed on married individuals living in Istanbul, Kasapoğlu and Yabanigül (2018) found marriage satisfaction to predict life satisfaction and spirituality, spirituality to predict life satisfaction, and spirituality to mediate the relationship between marital satisfaction and life satisfaction. McFarland, Uecker, and Regnerus (2011) explained religion and spirituality's positive impact on marital status through religion and spirituality's effect on increasing the frequency of married adults' sexual activities. Accordingly, married couples who increase their sexual satisfaction are also expected to increase their satisfaction in the relationship. As can be seen from these studies, increases in married individuals' spiritual orientations increases the couple's marital satisfaction and, as a result, their life satisfaction.

Based on the literature, spiritual orientation can be said to have a positive effect on both marital satisfaction and life satisfaction. However, what the factors of spirituality are that effect the increase in marital satisfaction and life satisfaction and 
over which factors does spirituality increase marital satisfaction and life satisfaction are not fully known. For this reason, this research has addressed sacrifice and sensitivity as mediating variables and looked at the direct and indirect effects of married individuals' spirituality on the happiness in their relationship and in their life satisfaction. When examining the mediating variables, sacrifice and sensitivity are seen related to spirituality as well as marital satisfaction and life satisfaction, and sacrifice and spirituality are seen to mediate the relationship of marital satisfaction and life satisfaction with spirituality.

When examining the research finding that revealed a relationship to exist between the variables of sensitivity and sacrifice with happy marriage and life satisfaction, this finding is seen to be consistent with the literature. A healthy marriage is only possible by spouses meeting each other's needs and expectations and maintaining their marriage in harmony with healthy and empathetic communication. Married individuals being able to establish clear and comfortable communication and both sides being able to solve their problems agreeably by arriving at a mutual compromise are important skills that increase marital harmony (Sabatelli, 1988). Sensitive individuals' having empathetic skills facilitates spouses' understanding of one another's feelings, needs, and expectations; therefore, couples who feel understood feel increased satisfaction from the marriage. On the other hand, because spouses get closer through understanding and being merciful towards each other, they rarely experience disputes or succeed in easily solving them.

Studies are available that have revealed the sensitivity of married individuals who have the factors of understanding, empathy, and compassion to positively impact spouses' marital satisfaction. The results from Ulloa, Hammett, Meda, and Rubalcaba's (2017) research reveal individuals' tendencies toward understanding, compassion, and sympathy to be related to the general satisfaction and feeling of love in romantic relationships. In research done on marital satisfaction, Chung (2014) determined empathy to be directly related to marital satisfaction and revealed the capability of empathy to be a significant factor in couples' developing closeness and marital satisfaction. Individuals with emotional intelligence are expected to possess qualities such as being sensitive, being empathetic, and being compassionate and understanding. Married individuals who are sensitive, empathetic, compassionate, and understanding are also thought to be happier in their marriage and to have higher marital satisfaction. The findings obtained from this research also support studies that have shown a relationship to exist between emotional intelligence and happiness (Afkhami-Aqda, Abedini, Serwat, Firozabadi-Ardakan, \& Nikokaran, 2014). Based on these findings, spouses' possessing healthy personal characteristics and values (e.g., sensitivity, sacrifice, empathetic listening, understanding, healthy communication, feeling respect for the spouse, supporting the spouse, and being forgiving) can be said 
to contribute significantly to marital satisfaction. Another finding from the research reveals a positive relationship to exist between sensitivity and sacrifice with spiritual orientation. Spirituality activates values in people, and the values individuals' possess also positively impact the harmony and satisfaction in their marriages.

Lastly, the structural model established in this research for testing the mediating role of sensitivity and sacrifice on the relationship between marital satisfaction and spiritual orientation has been confirmed; sensitivity and sacrifice are seen to have a partial mediating role in the model. The results obtained from this research need to be evaluated by considering the limitations of the research. The research group in this study is composed of married couples living in Turkey of all ages and from all regions and various socioeconomic levels; however, not examining the married individuals in terms of the regions where they live, culture, or socioeconomic levels can be seen as a limitation of this study. Separately examining the model in different age groups, regions, and socioeconomic levels is thought to be useful. Despite these limitations, this research is considered to contribute to the field, particularly in terms of having couple and family counselors or therapists see the various mechanisms that impact marital satisfaction and gain deeper understanding and awareness in this direction. In addition, developing and applying spiritually based psycho-education programs directed at increasing sensitivity and sacrifice between couples is considered to be useful for increasing married couples' happiness in their relationships and the satisfaction they obtain from marriage. When considering spirituality, sensitivity, and sacrifice's contribution to happiness and harmony in marriage and, as a result, to marriage satisfaction and ultimately to life satisfaction as based on the results of the research, importance is given to marriage and family counselors preparing programs and providing trainings and seminars on the issue of the importance of values such as spirituality, sensitivity, and sacrifice for marriage, family, and therefore society. Also, drawing researchers' attention to these issues and addressing them more comprehensively is thought to be important in terms of what their discussions will contribute to the literature and in terms of creating awareness in society.

\section{References}

Adams, D.L. (1971). Correlates of satisfaction among the elderly. Gerontologist, 11, 64-68

Afkhami-Aqda, M., Abedini, M., Serwat, F.L., Firozabadi-Ardakan, A. \& Nikokaran, J. (2014). A survey on the relation between EQ and marriage happiness of the married couples living in the city of Yazd. Toloo-e-behdasht, 13(4), 57-65.

Ahmadi, K., \& Hossein-Abadi, F. H. (2009). Religiosity, marital satisfaction and child rearing. Pastoral Psychology, 57, 211-221.

Alorani, O.I., \& Alradaydeh, M.F. (2017). Spiritual well-being, perceived social support, and life satisfaction among university students, International Journal of Adolescence and Youth, 1-8. doi: $10.1080 / 02673843.2017 .1352522$ 
Arasan, B. N. A. (2010). Akademisyenlerde yaşam doyumu, iş doyumu ve mesleki tükenmişlik düzeylerinin belirlenmesine yönelik bir araştırma. Uşak Üniversitesi.

Atta-Alla, M. F. N.(2009). Perceptions of marital satisfaction among Coptic Orthodox Christian Egyptian-American husbands and wives. Doctoral dissertation, Duquesne University, Pittsburgh, PA, USA. Retrieved from https://dsc.duq.edu/etd/253

Bennett, M.R. \& Einolf, C. J. (2017). Religion, altruism, and helping strangers: A multilevel analysis of 126 countries. Journal for the Scientific Study of Religion, 56(2), 323-341.

Bradbury, N.B., Fincham, F.D., \& Beach, S.R. (2000). Research on the nature and determinants of marital satisfaction: A decade in review. Journal of Marriage and the Family, 62, 964-980.

Call, V. R. A., \& Heaton, T. B. (1997). Religious influence on marital stability. Journal for the Scientific Study of Religion, 36(3), 382-392.

Carlson, T. D., Kirkpatrick, D., Hecker, L., \& Killmer, M. (2002). Religion, spirituality, and marriage and family therapy: A study of family therapists' beliefs about the appropriateness of addressing religious and spiritual issues in therapy. The American Journal of Family Therapy, 30(2), 157-171. doi:10.1080/019261802753573867

Celenk, O., \& van de Vijver, F. J. R. (2013a). What makes couples happy? Marital and life satisfaction among ethnic groups in the Netherlands. Journal of Cross-Cultural Psychology, 44(8) 1275-1293. doi: 10.1177/0022022113486003

Celenk, O., \& van de Vijver, F. J. R. (2013b). Perceived antecedents of marital satisfaction among Turkish, Turkish-Dutch, and Dutch couples. International Journal of Psychology, 48(6), 11651175. doi: 10.1080/00207594.2012.741242

Chung, M-S. (2014). Pathways between attachment and marital satisfaction: The mediating roles of rumination, empathy, and forgiveness. Personality and Individual Differences, 70, 246-251.

Çağ, P., \& Yıldırım, İ. (2013). Evlilik doyumunu yordayan ilişkisel ve kişisel değişkenler. Türk Psikolojik Danışma ve Rehberlik Dergisi, 4(39), 13-23.

Çelik, E. (2015). Evlilik Doyumu. Ahmet Akın- Eyüp Çelik (Ed.) Psikolojide Güncel Kavramlar III: Aile-Evlilik (s. 24-26) içinde. Ankara: Nobel Yayınları.

Çelik, M., \& Tümkaya, S. (2012). The relationship between job variables of life satisfaction and marital satisfaction of lecturers. Ahi Evran Üniversitesi Kırşehir Eğitim Fakültesi Dergisi (KEFAD), 13(1), 223-238.

Dağlı, A., \& Baysal, N. (2016). Yaşam Doyumu Ölçeği’nin Türkçe’ye uyarlanması: Geçerlik ve güvenirlik çalışması. Electronic Journal of Social Sciences, 15(59), 1250-1262.

David, P., \& Stafford, L. (2015). A relational approach to religion and spirituality in marriage: The role of couples' religious communication in marital satisfaction. Journal of Family Issues, 36(2), 232-249.

Demirci-Seyrek, Ö., Ersanlı, K., \& Tunç, T. (2016). Duyarlık Ölçeği. Elektronik Sosyal Bilimler Dergisi, 15(56), 284-294.

Diener, E., Emmons, R. A., Larsen, R. J., \& Griffin, S. (1985). The satisfaction with life scale. Journal of Personality Assessment, 49(1), 71-75.

Diener, E., \& Lucas, R. E. (1999). Subjective well-being: Three decades of progress. Psychological Bulletin, 125(2), 276-303.

Diener, E., Gohm, C., Suh, E., \& Oishi, S. (2000). Similarity of the relations between marital status and subjectivewell-being across cultures. Journal of Cross-Cultural Psychology, 31, 419-436. 
Diener, M. L., \& Diener McGavran, M.B. (2008). What makes people happy? A developmental approach to the literature on family relationships and well-being. In R. Larson and M. Eid (Eds.), The science of subjective well-being (pp. 347-375). New York: Guilford.

Dikmen, A.A. (1995). Kamu çalışanlarında iş doyumu ve yaşam doyumu (Yayımlanmamış Yüksek Lisans Tezi). Ankara Üniversitesi, Sosyal Bilimler Enstitüsü, Ankara.

Dilmaç, B., \& Ekşi, H. (2008). Meslek yüksek okullarında öğrenim gören öğrencilerin yaşam doyumları ve benlik saygılarının incelenmesi. Selçuk Üniversitesi Sosyal Bilimler Enstitüsü Dergisi, (20), 279-289.

Dowlatabadi, F. H., Saadat, S. \& Jahangiri, S. (2013). The Relationship between Religious Attitudes and Marital Satisfaction among married personnel of departments of education in Rasht City, Iran. International Journal of Advanced Studies in Humanities and Social Science, 1(6), 608615.

Erdoğan, S., \& Uslu, M. (2018). Evli bireylerin evlilik doyumu ve merhamet düzeyleri arasındaki ilişkinin incelenmesi. Ĕ̆itim Bilimleri Çalışmaları, 125-134.

Elkins, D.N., Hedstrom, L.J., Hughes, L.L., Leaf, J.A., \& Saunders, C. (1988). Toward a humanisticphenomenological spirituality: Definition, description, and measurement. Journal of humanistic Psychology, 28(4), 5-18.

Ersanl1, K., \& Kalkan, M. (2008). Evlilik ilişkilerini geliştirme (kuram ve uygulama). Ankara: Nobel Yayın Dağıtım.

Fincham, F. D., \& Bradbury, T. N. (1987). The assessment of marital quality: A reevaluation. Journal of Marriage and the Family, 49(4), 797-809.

Flanagan, J. C. (1978). A research approach to improving our life quality. American Psychologist, $33,138-147$.

Gilbert, P., \& Irons, C. (2005). Focused therapies and compassionate mind training for shame and self-attacking. In P. Gilbert (Ed.), Compassion: Conceptualisations, research and use in psychotherapy (pp. 263-325). New York, NY, US: Routledge.

Hawkins, D. N., \& Booth, A. (2005). Unhappily ever after: Effects of long-term, low-quality marriages on well-being. Social Forces, 84(1), 451-471. doi: 10.1353/sof.2005.0103

Hayes, A. F. (2018). Introduction to mediation, moderation, and conditional process analysis. New York: The Guilford Press.

Hayward, M., \& Zhang, Z. (2006). Gender, the marital life course, and cardiovascular disease in late midlife. Journal of Marriage and Family, 68(3), 639-657.

Heller, D., Watson, D., \& Ilies, R. (2006). The dynamic process of life satisfaction. Journal of Personality, 74(5), 1421-1450.

Hill, P. C., Pargament, K. I., Hood, R. W., McCullough, J. M. E., Swyers, J. P., Larson, D. B., \& Zinnbauer, B. J. (2000). Conceptualizing religion and spirituality: Points of commonality, points of departure. Journal for the theory of social behaviour, 30(1), 51-77.

Hu, L. T., \& Bentler, P. M. (1999). Cutoff criteria for fit indexes in covariance structural analysis: Conventional criteria versus new alternatives. Structural Equation Modeling, 6, 1-55.

Huber, J. T. \& Macdonald, D. A. (2012). An investigation of the relations between altruism, empathy, and spirituality. Journal of Humanistic Psychology, 52(2), 206-221.

Hünler, O. S., \& Gençöz, T. (2003). Boyun eğici davranışlar ve evlilik doyumu ilişkisi: Algılanan evlilik problemleri çözümünün rolü. Türk Psikoloji Dergisi, 18(51), 99-108. 
Kasapoğlu, A. (2007). İslam’a göre evlilikte eşler arasında uyum sorunu-inanç ve ahlâk uyumu. Bilimname, 12(1),137-161.

Kasapoğlu, F. (2015). Manevi Yönelim Ölçeği’nin geliştirilmesi: Geçerlik ve güvenirlik çalışması. İnönü Üniversitesi Eğitim Fakültesi Dergisi, 16(3), 51-68. doi: 10.17679/iuefd.16360640

Kasapoğlu, F. \& Yabanigül, A. (2018). Marital satisfaction and life satisfaction: The mediating effect of spirituality. Spiritual Psychology and Counseling, 3(2), 177-195. doi: 10.12738/ spc.2018.3.2.0048

Keser, A. (2005). Çalışma yaşamı ile yaşam doyumuna ilişkisine teorik bakış. İktisat Fakültesi Mecmuas1, 55(1), 897-913.

Koydemir, S., Selışı, Z. E., \& Tezer, E. (2005). Evlilik uyumu ve mükemmeliyetçilik boyutları arasındaki ilişkiler. Türk Psikolojik Danışma ve Rehberlik Dergisi, 3(23), 65-74.

Kublay, D., \& Oktan, V. (2015). Evlilik uyumu: Değer tercihleri ve öznel mutluluk açısından incelenmesi. Türk Psikolojik Danışma ve Rehberlik Dergisi, 5(44), 25-35.

Mahoney, A. (2010). Religion in families, 1999-2009: A relational spirituality framework. Journal of Marriage \& Family, 72(4), 805-827.

McDonald, J. E., Olson, J. R., Lanning, A. H., Goddard, H. W., \& Marshall, J. P. (2018). Effects of religiosity, forgiveness, and spousal empathy on marital adjustment. Marriage \& Family Review, 54(4), 393-416.

McFarland, M.J., Uecker, J. E., \& Regnerus, M. D. (2011). The role of religion in shaping sexual frequency and satisfaction: Evidence from married and unmarried older adults. Jounal of Sex Research, 48(2-3), 297-308. doi: 10.1080/00224491003739993

Myers, D. G., \& Diener, E. (1995). Who is happy?. Psychological science, 6(1), 10-19.

Neff, K. (2003). Self-compassion: An alternative conceptualization of a healthy attitude toward oneself. Self and Identity, 2(2), 85-101. doi:10.1080/15298860309032

Neff, K. D., Kirkpatrick, K. L. \& Rude, S. S. (2007). Self-compassion and adaptive psychological functioning. Journal of Research in Personality, 41, 139-154.

Neugarten, B.L., Havighurst, R.J., Tobin, S.S. (1961). The measurement of life satisfaction. Journal J Gerontol 16, 134-143.

Ng, K. M., Loy, J. T. C., Gudmunson, C. G., \& Cheong, W. (2009). Gender differences in marital and life satisfaction among Chinese Malaysians. Sex Roles, 60(1-2), 33-43.

Özer, M., \& Karabulut, Ö.Ö. (2003). Yaşlilarda yaşam doyumu. Geriatri, 6(2), 72-74.

Özmen-Süataç, A. (2010). Evlilik uyumunun kişilerarası tarz ve öfke açısından araştırılması (Yayınlanmamış yüksek lisans tezi). Ege Üniversitesi, İzmir.

Parker, J. A., Mandleco, B., Olsen-Roper, S., Freeborn, D., \& Dyches, T.T. (2011). Religiosity, spirituality, and marital relationships of parents raising a typically developing child or a child with a disability. Journal of Family Nursing, 17(1), 82-104.

Pavot, W., \& Diener, E. (1993). The affective and cognitive context of self-reported measures of subjective well-being. Social Indicators Research, 28(1), 1-20.

Perrone, K. M., Webb, L. K., \& Blalock, R. H. (2005). The effects of role congruence and role conflict on work, marital, and life satisfaction. Journal of Career Development, 31(4), 225-238.

Perrone-McGovern, K. M., Boo, J. N., \& Vannatter, A. (2012). Marital and life satisfaction among gifted adults. Roeper Review, 34(1), 46-52. 
Rosen-Grandon, J. R., Myers, J. E., \& Hattie, J. A. (2004). The relationship between marital characteristics, marital interaction processes, and marital satisfaction. Journal of Counseling \& Development, 82(1), 58-68. doi: 10.1002/j.1556-6678.2004.tb00286.x

Rusbult, C. E., Martz, J. M. \& Agnew, C. R. (1998). The investment model scale: Measuring commitment level, satisfaction level, quality of alternatives, and investment size. Personal Relationships, 5, 357-391.

Sabatelli, R. M. (1988). Measurement issues in marital research: A review and critique of contemporary survey instruments. Journal of Marriage and the Family, 50, 891-915.

Sawatzky, R., Gadermann, A., \& Pesut, B. (2009). An investigation of the relationships between spirituality, health status and quality of life in adolescents. Applied Research in Quality of Life, 4, 5-22.

Scheidler, J. A. (2008). Effects of perceived stress and perceived social support on marital satisfaction in doctoral students. Doctoral dissertation, Walden University, Washington, USA.

Spanier, G. B., \& Lewis, R. A. (1980). Marital quality: A review of the seventies. Journal of Marriage and the Family, 42(4), 825-839.

Sprecher, S., \& Fehr, B. (2005). Compassionate love for close others and humanity. Journal of Social and Personal Relationships, 22(5), 629-651. doi:10.1177/0265407505056439

Stosny, S. (2004). Compassion Power: Helping Families Reach Their Core Value. The Family Journal, 12(1), 58-63. doi:10.1177/1066480703259041

Sweeney, T. J., \& Witmer, J. M. (1991). Beyond social interest: Striving toward optimum health and wellness. Individual Psychology: Journal of Adlerian Theory, Research \& Practice, 47(4), 527-540.

Tabachnick, B.G., \& Fidell, L.S. (2001). Using multivariate statitics. MA:Allyn \& Bacon, Inc.

Tezer, E. (1997). Evlilik ilişkisinden sağlanan doyum: Evlilik Yaşamı Ölçeği. Psikolojik Danışma ve Rehberlik Dergisi, 2(7), 1-7.

Topçu, Ç., \& Tezer, E. (2013). Turkish Adaptation of Perceived Sacrifice Harmfulness Scale and Satisfaction with Sacrifice Scale. Turkish Psychological Counseling and Guidance Journal, 5(40), 176-185.

Tuterel-Kışlak, Ş. (2002). İlişkilerde Mutluluk Ölçeği (İMÖ): Güvenirlik ve geçerlik çalışması. Kriz Dergisi 10(1), 37-43.

Tutarel-Kışlak, Ş., \& Göztepe, I. (2012). Duygu dışavurumu, empati, depresyon ve evlilik uyumu arasındaki ilişkiler. Ankara Üniversitesi Sosyal Bilimler Enstitüsü Dergisi, 3(2), 27-46.

Ulloa, E., Hammett, J. F., Meda, N. \& Rubalcaba, S. (2017). Empathy and romantic relationship quality among cohabitating couples. Family Journal, 25(3), 208-214. doi: 10.1177/1066480717710644

Van Lange, P. A. M., Rusbult, C. E., Drigotas, S. M., Arriaga, X. B., Witcher, B. S. \& Cox, C. L. (1997). Willingness to sacrifice in close relationships. Journal of Personality and Social Psychology, 72, 1373-1395.

Whitton, S. W., Stanley, S. M. \& Markman, H. J. (2007). If I help my partner, will it hurt me? Perceptions of sacrifice in romantic relationships. Journal of Social and Clinical Psychology, 26(1), 64-92. doi: 10.1521/jscp.2007.26.1.64

Williams, K. (2003). Has the future of marriage arrived? A contemporary examination of gender, marriage and psychological well-being. Journal of Health and Social Behavior, 44, 470-487. 
Yılmaz-Güre, A. (2001). Esler arasındaki uyum, anne-baba tutumu ve benlik algısı arasındaki iliskilerin gelisimsel olarak incelenmesi.[The relationship between marital adjustment, parenting style and selfperception of children from different age groups]. Türk Psikoloji Dergisi, 47, 1-20.

Yetim, Ü. (2001). Toplumdan bireye insan resimleri. İstanbul: Bağlam Yayınc1lık.

Zaheri, F., Dolatian, M., Shariati, M., Simbar, M., Ebadi, A., Batool, S.T. \& Azghadi, H. (2016). Effective factors in marital satisfaction in perspective of Iranian women and men: A systematic review. Electronic Physician, 8(12), 3369-3377. doi: 10.19082/3369 